\title{
MECHANIZM ZADAŃ ZLECONYCH W PRAWIE SAMORZADDU TERYTORIALNEGO POLSKI I JAPONII - ROZWAŻANIA KOMPARATYSTYCZNE
}

Decentralizacja władzy publicznej, która na mocy art. 15 ust. 1 Konstytucji Rzeczypospolitej Polskiej z dnia 2 kwietnia 1997 r. (Dz. U. Nr 78, poz. 483, ze zm.) ma rangę zasady ustrojowej, w różnych krajach świata przybiera rozmaite kształty i ramy organizacyjno-prawne. Jedną z najdonioślejszych i najbardziej uniwersalnych emanacji tego procesu jest konstrukcja korporacji prawa publicznego (inaczej mówiąc: związku publicznoprawnego ${ }^{1}$ ), w szczególności zaś jej podstawowa kategoria w postaci samorządu ${ }^{2}$. Decydującymi czynnikami determinującymi kierunki rozwoju samorządności w danym kraju są niewątpliwie okoliczności historyczne jej dojrzewania oraz wpływające na ten proces uwarunkowania polityczne i społeczne (m.in. zbiorowe cechy społeczeństwa, tzw. dystans do władzy ${ }^{3}$ ). Postrzeganie decentralizacji administracji jedynie przez pryzmat Polski lub państw z naszego kręgu kultury prawnej jest wobec powyższego postawą nazbyt wąską, a co za tym idzie tworzy złudny obraz naturalności i oczywistości rozwiązań prawnych regulujących tę kwestię w naszym kraju.

Niezwykle interesującym przykładem znacząco odmiennego od rozwiązań polskich, a zarazem wysoce efektywnego systemu decentralizacji administracji publicznej w wymiarze terytorialnym jest Japonia. Kraj ten wykształcił na przestrzeni swojego rozwoju unikatowy system prawny, stanowiący efekt współoddziaływania z jednej strony powolnie i samoistnie dojrzewających rodzimych rozwiązań normatywnych, z drugiej zaś zaburzającego ten proces nagłego, acz historycznie powtarzalnego recypowania obcych (głównie europejskich oraz amerykańskich) wzorców w tym zakresie 4 . Zaistniały w ten sposób dualizm japońskich regulacji prawnych w relatywnie najmniejszym stopniu dotknął obszaru prawa administra-

ORCID: 0000-0001-6772-3789, DOI: 10.4467/23538724GS.20.020.12138

Zob. T. Bigo, Zwiqzki publiçno-prawne w śmietle ustawodawstwa polskiego, Warszawa 1928, s. 34.

Zob. J. Zimmermann, Prawo administracyjne, Warszawa 2014, s. 179.

Zob. G. Hofstede, Kultury i organizacje, tłum. M. Durska, Warszawa 2000, s. 77 i nn.

4 Zob. U. Wach-Górny, W. Górny, Między prawem a kultura - kilka uwag na temat recepcji zachodnich rozwiqzañ prawnych na japoński grunt spoteczno-kulturowy, „Gdańskie Studia Azji Wschodniej” 2015, z. 7, s. 106-120. 
cyjnego. Jakkolwiek bowiem współczesny kształt japońskiego prawa cywilnego, karnego czy konstytucyjnego w znacznym stopniu bazuje na konstrukcjach skopiowanych z zagranicy ${ }^{5}$, z czasem stopniowo japonizowanych, niemniej genetycznie obcych, prawo administracyjne stanowi w tym układzie jaskrawy wyjątek ${ }^{6}$. Historyczny rozwój administracji publicznej w Japonii, w tym dokonywanej na jej płaszczyźnie decentralizacji, stanowi przejaw metodycznej ewolucji rozwiązań stricte japońskich, będąc - jako jedyny obszar prawny niezakłócony przez recepcję obcych wzorców - swoistym dziedzictwem kultury prawnej tego kraju. Z tego właśnie powodu, charakteryzując japoński system administracji publicznej, większość badaczy eksponuje swoisty, wyróżniający ten kraj na tle innych systemów prawa administracyjnego, podział zdecentralizowanej w wymiarze terytorialnym części tego systemu (tzw. autonomii lokalnej) na autonomię zbiorową (samorząd terytorialny) oraz autonomię obywatelską (specyficzny japoński odpowiednik instytucji społeczeństwa obywatelskiego) ${ }^{7}$.

Drugą z koronnych cech charakterystycznych japońskiej samorządności - zdecydowanie mniej niż pojęcie autonomii lokalnej oraz jej podział ugruntowaną w literaturze, bo istniejąca dopiero od ostatniej dużej reformy japońskiego prawa administracyjnego w 1999 r. - jest niespotykanie głęboka decentralizacja administracji publicznej w ujęciu funkcjonalnym. Przejawia się ona istnieniem na płaszczyźnie samorządu terytorialnego (autonomii zbiorowej) swoiście japońskiej wersji mechanizmu zadań zleconych wraz z towarzyszącymi mu instrumentami prawnymi (m.in. rozbudowany system podatków lokalnych oraz tzw. mechanizm solidarnościowy) ${ }^{8}$. Celem prowadzonych w niniejszym artykule rozważań jest prezentacja założeń tego mechanizmu oraz zestawienie go z polskim odpowiednikiem, a w efekcie wyciagnięcie z przeprowadzonych $\mathrm{w}$ ten sposób analiz komparatystycznych wniosków de lege ferenda odnoszących się do polskiego ustawodawstwa. Rozróżnienie zadań własnych i zadań zleconych od lat funkcjonuje bowiem w obszarze polskiego systemu prawa samorządu terytorialnego. Trudno jednak postrzegać to zjawisko jako pogłębiające decentralizację jednostek samorządu terytorialnego w Polsce. Ów dysonans dobrych praktyk odnoszących się do mechanizmu zadań zleconych w Japonii z nie najlepszymi doświadczeniami Polski w tym zakresie, stanowi asumpt dla poszukiwania w rozwiązaniach japońskich inspiracji dla polskiego ustawodawcy.

Na potrzeby tak zarysowanych rozważań artykuł będzie obejmował następujące zagadnienia: 1) krótki zarys ewolucji samorządu terytorialnego (autonomii zbiorowej)

5 Zob. J. Widacki, Przestępczość i mymiar sprawiedliwości karnej w Japonii, Lublin 1990, s. 76.

6 Zob. U. Wach-Górny, W. Górny, Mięsyy prawem a kulturq..., s. 114 i nn.

7 Zob. W. Górny, Japońskie inspiracje dla rožwoju samorzadności lokalnej w Polsce, „Gdańskie Studia Azji Wschodniej” 2018, z. 13, s. 155 i nn.

${ }^{8}$ Zob. W. Górny, Samorzqd terytorialny w Japonii, cayli paradoks dynamicznego rozwoju autonomii obywatelskiej w warunkach ograniczonej decentralizacji [w:] Wspótczesna Japonia. Dylematy i wyz̧wania, red. J. Marszałek-Kawa, K. Skonieczka, Toruń 2014, s. 119. 
w Japonii, obrazujący historyczne uwarunkowania kształtowania się aktualnego modelu; 2) charakterystykę rozwiązań decentralizujących administrację publiczną w ujęciu funkcjonalnym, które zostały przyjęte na bazie reformy japońskiego prawa administracyjnego (w tym prawa samorządu terytorialnego) z 1999 r., a także zestawienie ich założeń z polskimi odpowiednikami; 3) analizę możliwości skorzystania ze sprawdzonych w ostatnich 20 latach mechanizmów japońskich przy wprowadzaniu zmian w polskim prawie samorządu terytorialnego. Odpowiadające celom naukowym niniejszego opracowania, zastosowane w pracy metody badawcze to w szczególności analiza normatywna oraz doktrynalna polskiego (w tym europejskiego) i japońskiego prawa samorządu terytorialnego, uzupełniona o metode historycznoprawną oraz analizę komparatystyczną (komparatystyka funkcjonalna).

\section{Samorząd terytorialny w Japonii - burzliwe losy autonomii zbiorowej}

Historia administracji lokalnej w Japonii składa się z kilku dających się wyodrębnić okresów, charakteryzujących się odmiennymi - właściwymi dla poszczególnych epok w dziejach tego państwa - założeniami aksjologicznymi oraz organizacyjno-prawnymi.

Pierwszym etapem ewolucji zarządu lokalnego w Japonii był funkcjonujacy do lat 70. XIX wieku podział kraju na przeszło dwieście jednostek terytorialnych o nazwie han (klan). Na czele hanu stał pan feudalny, którego autorytarne, niczym nieograniczone kompetencje władcze obejmowały zarówno gospodarkę, jak i mieszkańców podległego mu terytorium. Ten typowo feudalny system zarządu lokalnego, niemający oczywiście nic wspólnego z jakimikolwiek przejawami decentralizacji administracji publicznej, został zniesiony dopiero w dobie reform cesarza Meiji (1868-1912). W ich wyniku wprowadzono dwustopniowy zasadniczy podział terytorialny kraju na prefektury i gminy, a powstałym w ten sposób jednostkom administracyjnym nadawano stopniowo coraz szersze uprawnienia, prowadzące do ukształtowania się podwalin współczesnej autonomii zbiorowej. Rozkwit zbudowanego w okresie Meiji samorządu terytorialnego przypadł na lata 20. XX wieku, kiedy to funkcjonujące już w oparciu o odnoszące się do nich bezpośrednio akty normatywne (tzw. kodeksy prefekturalne) jednostki samorządu terytorialnego osiagnęły bardzo wysoki jak na owe czasy poziom samodzielności zarówno na płaszczyźnie ustrojowej (m.in. zgromadzenia prefekturalne), jak i kompetencyjnej oraz finansowej'. Znaczący regres w tym zakresie nastapił w latach 30. XX wieku. Rozwój nastrojów nacjonalistycznych, a także powiązana z agresywna polityka za-

9 Zob. J. Tubielewicz, Historia Japonii, Wrocław 1984, s. 56. 
graniczna Japonii (konflikty zbrojne $\mathrm{z}$ lat 30. i 40. XX wieku) skrajna centralizacja władzy w kraju nie ominęły także systemu władzy lokalnej ${ }^{10}$. Jednostki zasadniczego podziału terytorialnego państwa oraz ich organy, mimo dalszego formalnego funkcjonowania, stały się instytucjami fasadowymi, w pełni podporządkowanymi wytycznym Ministerstwa Spraw Wewnętrznych, które realizowało militarystyczne założenia władz centralnych Japonii.

Zupełnie nowym otwarciem dla rozwoju samorządności terytorialnej w Japonii okazało się wejście w życie Konstytucji Shōwa ${ }^{11}$, która stanowiła efekt powojennej amerykańskiej okupacji kraju. W rozdziale VIII (art. 92-95) Konstytucji, zatytułowanym „Samorząd terytorialny” jednoznacznie przesądzono o systemowej decentralizacji władzy publicznej, a ponadto znalazły się tu ustrojowe i funkcjonalne podwaliny dla realizacji konstytucyjnej zasady autonomii lokalnej, wprowadzonej na mocy art. 92 in fine $e^{12}$. Ponieważ przywołana regulacja konstytucyjna rozstrzyga jedynie najbardziej rudymentarne zagadnienia odnoszące się do decentralizacji władzy publicznej w wymiarze terytorialnym, rzeczywista podstawa prawną funkcjonowania samorzadu terytorialnego w Japonii jest ustawa o autonomii lokalnej z $1947 \mathrm{r}^{13}$, uchwalona jako realizacja delegacji zawartej w art. 92 Konstytucji Shōwa. Pierwotny tekst ustawy, ukształtowany pod wydatnym wpływem władz okupacyjnych, zakładał wyposażenie organów jednostek samorządu terytorialnego w realne kompetencje administracyjne, które pozwalają na wykonywanie władzy publicznej w wymiarze lokalnym, zgodnie z ogólną klauzulą kompetencyjną zawartą w art. 94 Konstytucji Shōwa.

Zdecydowanie niekorzystna z punktu widzenia decentralizacji administracji publicznej zmiana nastąpiła w tym zakresie w $1960 \mathrm{r}$. Wprowadzona wówczas nowelizacja ustawy o autonomii lokalnej drastycznie ograniczyła bezpośrednie kompetencje organów prefektur oraz gmin, powierzając realizację znacznej części zadań publicznych o charakterze lokalnym (przede wszystkim w obszarze edukacji i bezpieczeństwa publicznego) władzom centralnym, które mogły w drodze porozumienia administracyjnego przekazywać ich wykonanie właściwym miejscowo organom jednostek samorządu terytorialnego. Skonstruowany w ten sposób system podziału kompetencji w zakresie wykonywania władzy publicznej na szczeblu lokalnym na kilkadziesiąt lat drastycznie wyhamował rozwój autonomii zbiorowej w Japonii. Przyczynił się do centralizacji władzy i wzmocnienia pozycji politycznej administracji rządowej względem samorządu terytorialnego, w znacznym stopniu zależnego od rządu w sferze kompetencyjnej oraz finansowej (system zadań zleconych opartych na porozumieniu administracyjnym) ${ }^{14}$.

10 Zob. K. Michihiro, Local Government in Japan, Tokyo 2010, s. 5.

11 Konstytucja Japonii, tłum. i wstęp T. Suzuki, Warszawa 2014.

12 Zob. G. Kryszeń, Japonia [w:] Systemy ustrojowe państw wspótczesnych, red. S. Bożyk, M. Grzybowski, Białystok 2012, s. 441 i nn.

13 Local Autonomy Law (No. 67 of 1947).

14 Zob. H. Tanaka, Evaluation in Local Governments in Japan, Tokyo 2009, s. 20. 
Postępująca krytyka polityczna i doktrynalna ${ }^{15}$ zarysowanego w ten sposób, wyraźnie dysfunkcjonalnego systemu władzy lokalnej w Japonii, opartego na dualizmie zadań samorządu terytorialnego, ze zdecydowana przewaga zadań zleconych mu przez rząd centralny, doprowadziła do przeprowadzenia w 1999 r. gruntownej reformy ustawy o autonomii lokalnej. Jej podstawowe założenia zostały odniesione nie do ustrojowego wymiaru samorządu, ale do istniejących w nim zagadnień natury kompetencyjnej i finansowej ${ }^{16}$. W sferze instytucjonalnej utrzymano więc funkcjonujący (z drobnymi zmianami) od $1888 \mathrm{r}$. dwustopniowy podział terytorialny kraju na prefektury (47) oraz gminy (ponad 1700). Stosownie do postanowień art. 93 Konstytucji Shōwa organy tych jednostek wyłaniane są w wyborach powszechnych. W prefekturach sa to zgromadzenia prefekturalne jako ciała uchwałodawczo-kontrolne i gubernatorzy jako organy wykonawcze, zaś w gminach: zgromadzenia gminne (miejskie, miasteczkowe lub wiejskie) jako organy uchwałodawczo-kontrolne i wójtowie lub burmistrzowie miast jako organy wykonawcze. Szczególnie mocna pozycję ustrojową czerpia z takiego sposobu wyboru jednoosobowe organy wykonawcze (gubernatorzy oraz wójtowie lub burmistrzowie miast), którym japońskie ustawodawstwo samorządowe poza klasycznymi uprawnieniami (m.in. role kierownicze i reprezentacyjne) przyznaje liczne kompetencje natury koordynacyjnej, zarówno w obszarze administracji lokalnej sensu stricto, jak i wobec tzw. komitetów administracyjnych (m.in. Komisja Bezpieczeństwa i Porządku Publicznego, Kuratorium Oświaty, Komisja Wyborcza) ${ }^{17}$.

\section{Mechanizm zadań zleconych, czyli „papierek lakmusowy” samorządności terytorialnej}

Mimo wspomnianego braku istotnych zmian natury ustrojowej, reforma samorządu terytorialnego w Japonii, która została przeprowadzona nowelizacją ustawy o autonomii lokalnej z $1999 \mathrm{r}^{18}$, doprowadziła do zasadniczego przewartościowania pojęcia decentralizacji władzy publicznej w tym kraju. Skupiając się na precyzyjnym ustaleniu relacji pomiędzy administracją rządową a prefekturami i gminami, na nowo zdefiniowała ona funkcjonalny oraz finansowy wymiar japońskiej

\footnotetext{
15 Zob. M. Michio, Local Power in the Japanese State, Berkeley 1997, s. 10.

16 Zob. K. Hitoshi, Shin chibo jichi ho - New local autonomy law, Tokyo 1999, s. 4.

17 Zob. S. Ohsugi, The Organisation of Local Government Administration in Japan, Tokyo 2009, s. 13 i nn.; W. Górny, Japońskie inspiracje..., s. 154, 155.

18 Revised Local Autonomy Law (No. 117 of 1999), tekst w języku angielskim dostępny pod adresem: http://nippon.zaidan.info/seikabutsu/1999/00168/mokuji.htm (dostęp: 27.04.2020).
} 
samorządności terytorialnej ${ }^{19}$. Kluczowym pojęciem dla tych zmian był mechanizm zadań zleconych, stanowiący rdzeń wspomnianej reformy.

Zadania zlecone są stosowaną dość powszechnie w prawodawstwie administracyjnym wielu państw świata konstrukcją prawną swoistego „kanału transmisyjnego", za pomocą którego administracja rządowa deleguje wykonywanie części swoich kompetencji w ręce samorządu powszechnego. Jak wskazuje się w literaturze przedmiotu: „niektóre zadania państwo zdecydowało się przekazać samorządowi terytorialnemu w całości, a niektóre pozostawiło administracji rządowej z utrzymaniem możliwości ich zlecenia samorządowi. O takiej decyzji ustawodawcy przesadziło (...), czy dane zadanie powinno być wykonywane w całym państwie w sposób jednolity (...), czy też zachowanie tej jednolitości nie jest konieczne, a odwrotnie: korzystniejsze jest zróżnicowanie tej działalności w zależności od czynników lokalnych"20. Z uwagi na umiejscowienie w newralgicznym punkcie systemu administracji publicznej, tj. pomiędzy administracją rządową a samorządową, mechanizm zadań zleconych stanowi wyjątkowo czuły miernik rzeczywistej pozycji ustrojowej samorządu powszechnego. Szczególna podatność konstrukcji zadań zleconych na oddziaływanie czynników politycznych ${ }^{21}$ - tak przecież charakterystycznych dla prawa administracyjnego in genere - powoduje, że sposób ustawowego ukształtowania zakresu zadań zleconych, a przede wszystkim metody ich przekazywania administracji samorządowej (w tym zapewnienia właściwego finansowania ich realizacji) w zasadniczy sposób determinuje rzeczywistą efektywność decentralizacji administracji publicznej w danym państwie.

Podstawą polskiej regulacji prawnej odnoszącej się do instytucji zadań zleconych jest art. 8 ustawy z dnia 8 marca 1990 r. o samorzadzie gminnym (tekst jedn.: Dz. U. z 2020 r., poz. 713). W ust. 1 wspomnianego artykułu wskazano, że ustawy moga nakładać na gminę obowiązek wykonywania zadań zleconych z zakresu administracji rządowej, a także z zakresu organizacji przygotowań i przeprowadzenia wyborów powszechnych oraz referendów, zaś w ust. 2 ustawodawca doprecyzował, iż zadania z zakresu administracji rządowej gmina może wykonywać również na podstawie porozumienia z organami tej administracji. Mimo braku literalnych odpowiedników powyższej regulacji w ustawie $\mathrm{z}$ dnia 5 czerwca 1998 r. o samorządzie powiatowym (tekst jedn.: Dz. U. z 2019 r., poz. 1571) oraz ustawie z dnia 5 czerwca 1998 r. o samorządzie województwa (tekst jedn.: Dz. U. z 2019 r., poz. 512) przyjmuje się, że mechanizm zadań zleconych $\mathrm{w}$ analogicznej do opisanej w przywołanym przepisie

19 Zob. Japan's Road to Pluralism: Transforming Local Communities in the Global Era, eds. F. Shun'ichi, M. Toshihiro, Tokyo 2003, s. 23.

20 J. Zimmermann, Prawo administracyjne..., s. 222.

21 M. Zirk-Sadowski, Metodologie teorii prawa a problem polityczności prawoznawstwa. Aspekt behawioralny $i$ intensjonalny [w:] Polityczność nanki prawa i praktyki prawniczej, red. A. Bator, P. Kaczmarek, Wrocław 2017, s. 49. 
formie funkcjonuje na płaszczyźnie samorządów wszystkich trzech szczebli zasadniczego podziału terytorialnego państwa ${ }^{22}$.

Z uwagi na nie do końca oczywisty charakter analizowanego podziału w literaturze przedmiotu wskazuje się na różne czynniki pozwalające na odróżnienie zadań zleconych od zadań własnych samorządu terytorialnego ${ }^{23}$. Najistotniejszym z nich jest źródło kompetencji do podejmowania działań administracyjnych przez organy jednostek samorządu terytorialnego. W przypadku zadań własnych, których realizacja stanowi z założenia główny cel działania samorządu, podstawą ich wykonywania jest generalna i ogólna klauzula kompetencyjna zawarta w ustawie. Każda z ustaw samorządowych zawiera w swojej treści przepis, w którym ustawodawca wskazuje cele powołania określonej jednostki samorządu terytorialnego, zakreślając tym samym jej podstawowe zadania własne.

Zgoła odmiennie rzecz się ma w odniesieniu do zadań zleconych. Z samej ich istoty wynika konieczność przekazania kompetencji do realizacji określonego działania administracyjnego przez organ administracji rządowej organowi jednostki samorządu terytorialnego, co dokonuje się albo na mocy regulacji ustawowej, albo na podstawie porozumienia administracyjnego ${ }^{24}$ zawartego $\mathrm{w}$ tym zakresie pomiędzy oboma zaangażowanymi w sprawę organami administracji publicznej. Wybierając pierwsze z tych rozwiązań, ustawodawca decyduje się wprawdzie na pozostawienie kompetencji administracyjnej w rękach właściwego organu administracji rządowej (najczęściej decyduje o tym potrzeba relatywnie jednolitego w skali całego kraju wykonywania określonego zadania publicznego), już na płaszczyźnie ustawowej przesądzając jednak, że jego rzeczywiste wykonywanie powierzone zostaje organowi jednostki samorządu terytorialnego. W przypadku zlecania zadania w drodze porozumienia decyzja co do sposobu jego wykonania jest po stronie organu administracji rządowej. To on bowiem, jednostronnie zobowiązując organ jednostki samorządu terytorialnego do wykonania określonego zadania publicznego, kreuje w tym celu stosowne upoważnienie, którego treść może być sformułowana ogólnie (podobnie jak w przypadku zlecenia ustawowego) lub przeciwnie - bardzo szczegółowo. Przyjęcie ostatniego z przywołanych rozwiązań znacznie ogranicza swobodę organu jednostki samorządu terytorialnego w wykonywaniu zadania zleconego, czyniąc zeń często de facto mechanicznego wykonawcę politycznych założeń administracji rządowej w tym zakresie.

Funkcjonujące na gruncie polskiego ustawodawstwa literalne dopuszczenie szerokiego zakresu delegowania zadań zleconych na mocy faworyzujących stronę rzadowa porozumień administracyjnych jest o tyle niewłaściwe, że Polskę wiąże akt prawa międzynarodowego w postaci Europejskiej Karty Samorządu Terytorialnego,

22 Zob. J.P. Tarno, Pojecie $i$ istota samorzadu terytorialnego [w:] Samorzad terytorialny w Polsce, red.

J.P. Tarno, M. Sieniuć, J. Sulimierski, J. Wyporska, Warszawa 2004, s. 22 i nn.

23 Zob. ibidem, s. 39 i nn.

24 Zob. J. Zimmermann, Prawo administracyjne..., s. 383. 
sporządzonej w Strasburgu dnia 15 października 1985 r. (Dz. U. z 1994 r. Nr 124, poz. 607). Ta zaś w art. 4 ust. 5 stanowi, że w przypadku delegowania kompetencji społecznościom lokalnym przez organy władzy centralnej lub regionalnej powinny one, w miarę możliwości, mieć pełną swobodę dostosowania sposobu wykonywania tych kompetencji do warunków miejscowych. Istniejąca w przedmiotowym zakresie regulacja ustawowa nie tworzy po stronie organu jednostki samorządu terytorialnego skutecznych gwarancji przestrzegania tego założenia.

Dopełnieniem występujących na tej płaszczyźnie problemów są - systematycznie sygnalizowane przez przedstawicieli środowisk samorządowych oraz doktryny ${ }^{25}$ - komplikacje praktyczne, wynikające $z$ wadliwości systemu finansowania realizacji zadań zleconych. Co do zasady bez zapewnienia niezbędnych środków finansowych na realizację zadania zleconego jednostki samorządu terytorialnego nie mają obowiązku ich wykonywania ${ }^{26}$. W praktyce jednak, w celu zaspokojenia potrzeb wspólnoty samorządowej, władze lokalne realizują wiele zadań, na które strona rządowa nie zapewniła środków finansowych lub zapewniła je w stopniu niewystarczającym. Powszechność tego typu przypadków powoduje, że dotacje celowe $z$ budżetu państwa na zadania z zakresu administracji rządowej oraz na inne zadania zlecone ustawami, a także na zadania realizowane przez jednostki samorządu terytorialnego na mocy porozumień zawartych z organami administracji rządowej (art. 8 ust. 1 pkt 1 i 2 ustawy z dnia 13 listopada 2003 r. o dochodach jednostek samorządu terytorialnego, tekst jedn.: Dz. U. z 2020 r., poz. 23) stanowią częsty przedmiot sporów sądowych toczących się pomiędzy zaangażowanymi w sprawę jednostkami samorządu terytorialnego a Skarbem Państwa ${ }^{27}$.

Jeszcze mniej korzystna dla samorządu terytorialnego w tym zakresie sytuacja prawna dotycząca mechanizmu zadań zleconych występowała - jak wspomniano w Japonii w latach 1960-1999. Przeprowadzona w 1960 r. nowelizacja ustawy o autonomii lokalnej, choć nie zrewolucjonizowała ustroju samorządu terytorialnego, to urzeczywistniła daleko idące zmiany w funkcjonalnym wymiarze administracji publicznej na szczeblu lokalnym, uzależniając de facto całkowicie władze prefektur oraz gmin od politycznej woli administracji rządowej. Wykorzystanie bardzo rozbudowanego systemu zadań zleconych, delegowanych samorządom przez rząd centralny za pomoca porozumień administracyjnych, a także finansowe uzależnienie skutecznej realizacji tych zadań od przekazania na nie stosownej dotacji

25 Zob. Zadania zlecone do lamusa? NIK za, MF milcsy, a pieniedzy od tego nie prazbędzie, „Gazeta Prawna.pl" 6.10.2017, https://www.gazetaprawna.pl/amp/1076056,zadania-zlecone-do-lamusanik-za-mf-milczy-a-pieniedzy-od-tego-nie-przybedzie.html (dostęp: 28.04.2020).

26 Zob. J. Zimmermann, Prawo administracyjne..., s. 223.

27 Zob. Pozew za zlecone. Miasto Ciechanów pozwato Skarb Państwa, chcac odzyskać ponad 6 mln zt za wykonywanie zadań zleconych, Serwis Samorządowy PAP, 22.03.2019, https://samorzad.pap.pl/kategoria/archiwum/pozew-za-zlecone-miasto-ciechanow-pozwalo-skarb-panstwa-chcac-odzyskacponad-6 (dostęp: 28.04.2020). 
powodowało, że zadania własne gmin i prefektur stały się jedynie dodatkiem do czysto wykonawczej i instrumentalnej roli tych jednostek, wynikającej z faworyzującej rząd regulacji ustawowej ${ }^{28}$. Będąca efektem tego stanu rzeczy fasadowość samorządu terytorialnego, a także decentralizacja administracji publicznej in genere zmobilizowały władze Japonii do podjęcia zdecydowanych działań w kierunku modyfikacji prawa, w rewolucyjny sposób zmieniających rozkład kompetencji w zakresie realizacji zadań publicznych.

Przyjęta przez parlament Japonii w czerwcu 1993 r. ustawa o promocji decentralizacji ${ }^{29}$ rozpoczęła żmudny, trwający niemal 5 lat proces negocjacyjnego wypracowywania regulacji prawnych, które miały zwiększyć efektywność i samodzielność kompetencyjno-finansowa gmin i prefektur ${ }^{30}$. Komitet Promocji Decentralizacji (ang. Decentralization Promotion Committee), w którego skład weszli przedstawiciele strony rządowej, samorządowej i eksperckiej, w latach 1995-1997 przygotował cztery raporty rekomendacyjne. $\mathrm{Na}$ ich podstawie rząd Japonii przyjął w 1998 r. plan promocji decentralizacji, którego newralgicznym punktem była uchwalona w lipcu 1999 r., a obowiązująca od kwietnia 2000 r. nowelizacja ustawy o autonomii lokalnej. Nurtem przewodnim wprowadzonych w tej regulacji zmian było drastyczne pogłębienie decentralizacji administracji publicznej w ujęciu funkcjonalnym poprzez ustanowienie ustawowego domniemania kompetencji w realizacji zadań publicznych na rzecz władz lokalnych (władze centralne Japonii wykonują obecnie właściwie wyłącznie zadania o charakterze stricte ogólnokrajowym, jak np. polityka zagraniczna i obronna, emisja pieniądza) oraz oparcie nielicznych pozostałości zadań zleconych na wyłącznie ustawowej delegacji do ich wykonywania. Rezygnacja z wykorzystywania w tym kontekście instytucji porozumienia administracyjnego oraz uczynienie z zadań zleconych materii ustawowej znacząco wzmocniły pozycję gmin i prefektur wobec rządu centralnego, którego rola w procesie ich wykonywania została ograniczona jedynie do następczej kontroli efektów działań swobodnie prowadzonych w tym zakresie przez jednostki samorządu terytorialnego ${ }^{31}$.

Równolegle z pogłębieniem samodzielności kompetencyjnej gmin i prefektur znacząco zdecentralizowano system redystrybucji publicznych środków finansowych. Na dochody jednostek samorządu terytorialnego Japonii po wprowadzonych zmianach składają się: podatki lokalne ustanawiane uchwałą ich organów stanowiących; samorządowy mechanizm solidarnościowy koordynowany przez rząd; dotacje państwowe oraz lokalne obligacje będące pozostałością mechanizmu zadań zleconych. Szczególnie pierwsze dwa z tych źródeł przesądzają o rzeczywistej i stanowiącej fenomen w skali globalnej samodzielności finansowej japońskiego samorządu

28 Zob. K. Michihiro, Local Government..., s. 7.

29 The Decentralization Promotion Law (No. 121 of 1993).

${ }^{30}$ K. Toshiyuki, Vectors of Change in Japan's Political and Fiscal Decentralization, „Social Science Japan Journal" 2007, vol. 37, issue 9, s. 5.

31 Zob. K. Michihiro, Local Government..., s. 17. 
terytorialnego. Wyjątkowość japońskich podatków lokalnych na tle ich odpowiedników w innych państwach świata wynika z różnorodności składających się nań danin (m.in. podatek mieszkalny, podatek od przedsiębiorstw, podatek od konsumpcji) oraz z korzystnej dla samorządu proporcji udziału tych podatków w ogóle przychodów państwa. W Japonii aż ok. $60 \%$ wszystkich przychodów publicznych stanowi przychód z rozmaitych podatków lokalnych ${ }^{32}$. Znaczy to, że uzyskane w ten sposób środki finansowe bezpośrednio i bez jakiegokolwiek udziału rządu centralnego zasilają budżety właściwych miejscowo prefektur i gmin. Ten znaczący i pewny (niezależny od bieżącej sytuacji politycznej w kraju) udział jednostek samorządu terytorialnego w dochodach publicznych przesądza o ich głębokiej decentralizacji i rzetelności w wypełnianiu zadań publicznych.

W równie korzystny dla samorządów sposób rozwiązana jest w Japonii kwestia tzw. mechanizmu solidarnościowego, występująca w systemach prawnych wielu państw świata. Jego założeniem nie jest, jak w wielu innych krajach, w tym w Polsce, „składanie się" bogatszych jednostek samorządu terytorialnego na ich gorzej prosperujące odpowiedniki. Japoński mechanizm solidarnościowy (ang. Local allocation Tax) zakłada funkcjonowanie funduszu solidarnościowego zasilanego przez rząd centralny z ustawowo określonych części podatków ogólnokrajowych, m.in. podatku dochodowego od osób fizycznych (PIT), podatku dochodowego od osób prawnych (CIT), podatku od towarów i usług (VAT) oraz akcyzy. Zgromadzone w ten sposób środki są następnie obligatoryjnie rozdysponowywane między jednostki samorządu terytorialnego posiadające, $z$ uwagi na ich strukturę demograficzno-gospodarcza, gorszą sytuację finansowa. W taki sposób, bez obciążania samych samorząáów, za pomoca ustawowo zdeterminowanej (a co za tym idzie - niezależnej od uwarunkowań politycznych) koordynacji rządu centralnego dokonuje się w Japonii wspieranie tych samorządów, które z uwagi na trudne uwarunkowania mogłyby sobie nie radzić z efektywnym wypełnianiem delegowanych im przez ustawy zadań publicznych ${ }^{33}$.

\section{Japońskie inspiracje w zakresie efektywnej decentralizacji administracji publicznej w ujęciu funkcjonalnym}

Mijająca w tym roku 30. rocznica reaktywacji samorządu terytorialnego w Polsce skłania do refleksji nad skutecznością obowiązujących w tym zakresie rozwiązań prawnych. W doktrynie od lat pojawiają się głosy podnoszące potrzebę terminologicznego, systemowego oraz funkcjonalnego uporządkowania prawa samorządu terytorialnego (m.in. postulat rezygnacji z wielości ustaw samorządowych na rzecz

32 Ibidem, s. 25.

33 Ibidem, s. 18. 
tzw. kodeksu samorządu terytorialnego $\left.{ }^{34}\right)$. Mimo znaczacych barier politycznych (m.in. przyzwyczajenie do istniejącego systemu oraz brak woli samoograniczania kompetencji władz centralnych kosztem pogłębiania samodzielności jednostek samorządu terytorialnego) gruntowna reforma polskiego samorządu wydaje się w najbliższych latach nieunikniona. Mając na względzie perspektywę konieczności jej przeprowadzenia, warto, z zachowaniem niezbędnego dystansu oraz właściwych proporcji, wnikliwie zapoznać się z zagranicznymi rozwiązaniami w tym zakresie, które - choć często na pozór nieprzystające do polskich uwarunkowań - mogą okazać się doskonałą inspiracją dla działań rodzimego ustawodawcy.

Podążając tropem zasygnalizowanego powyżej zestawienia polskich i japońskich rozwiązań prawnych w zakresie decentralizacji administracji publicznej w ujęciu funkcjonalnym, można by wskazać kilka wzorców bądź dobrych praktyk, pochodzacych z dokonanej w Japonii w 1999 r. reformy samorządu terytorialnego.

Pierwszą z takich inspiracji mogłaby być znacząca korekta proporcji zadań własnych i zleconych jednostek samorządu terytorialnego na korzyść mechanizmów afirmujących samodzielne, niezależne od woli władz centralnych wykonywanie zadań publicznych przez samorząd terytorialny. Ograniczenie zakresu zadań zleconych oraz - jeśli mimo wszystko są one w określonej sferze działalności państwa nieodzowne - oparcie delegacji do ich wykonywania na normie ustawowej, nie zaś porozumieniu administracyjnym, w istotny sposób pogłębiłoby decentralizację administracji publicznej w ujęciu funkcjonalnym, przyczyniając się do wzrostu efektywności w wykonywaniu zadań publicznych w wymiarze lokalnym.

Za udoskonaleniami natury kompetencyjnej mogłyby podążyć - inspirowane japońskimi doświadczeniami - modyfikacje sposobu finansowania samorząu terytorialnego. Zarysowane powyżej zwiększenie udziału jednostek samorządu terytorialnego w wykonywaniu zadań publicznych mogłoby bowiem znaleźć odzwierciedlenie zarówno we wzorowanej na modelu japońskim rozbudowie systemu podatków lokalnych (kosztem podatków ogólnokrajowych), jak i w wykreowaniu analogicznego do osiagnięć japońskich mechanizmu solidarnościowego - skutecznego i ekonomicznie racjonalnego. Funkcjonujące obecnie w tym zakresie w Polsce tzw. janosikowe od lat stanowi przedmiot pogłębionej krytyki przedstawicieli środowisk samorządowych (m.in. Związku Miast Polski), wskazujacych na konfliktogenny ${ }^{35}$ oraz demobilizujacy ekonomicznie ${ }^{36}$ wymiar tego mechanizmu ${ }^{37}$.

34 Zob. W. Kisiel, Prawo o ustroju samorzqdu terytorialnego: założenia gruntownej reformy, Kraków 2014, s. 44 i nn.

35 Chodzi o kreowanie antagonizmów pomiędzy bogatszymi i biedniejszymi jednostkami samorządu terytorialnego jako odpowiednio płatnikami oraz beneficjentami janosikowego.

36 Chodzi o zniechęcanie bogatych samorządów do zwiększania przychodów poprzez „przyciaganie" podmiotów gospodarczych groźbą konieczności przekazywania nadwyżki przychodu na rzecz funduszu solidarnościowego.

37 Zob. M. Jantos, „Janosikowe” mymaga żmian, Magiczny Kraków, 16.01.2020, https://www.krakow. pl/aktualnosci/236464,30,komunikat,_janosikowe_wymaga_zmian.html (dostęp: 28.04.2020). 
Poza aspektem funkcjonalnym oraz finansowym doświadczenia japońskie dostarczają również cennych wskazówek w zakresie sposobu przeprowadzenia procesu przygotowywania oraz wdrażania ewentualnej reformy samorządowej w Polsce. Wynikające z mentalności Japończyków oraz ich nastawienia do spraw publicznych ${ }^{38}$ metodyczność i niespieszność w pracach nad nowelizacją ustawy o autonomii lokalnej wydają się wzorcem zdecydowanie godnym powielenia. Podobnie rzecz się ma ze swoistym dla Japonii, acz stosowanym nie tylko tam ${ }^{39}$, negocjacyjnym modelem tworzenia regulacji, zastosowanym przy przygotowaniu reformy. Wielość interesariuszy regulacji prawa samorządu terytorialnego wymaga bowiem, aby odnosząca się doń reforma była przygotowywana z udziałem szerokiego grona jej potencjalnych odbiorców.

\section{Podsumowanie}

Mimo położenia w odległych częściach świata oraz reprezentowania dalece odmiennego nastawienia do prawa Polskę i Japonię łączy - głębsza często niż w przypadku wielu bliższych nam geograficznie i kulturowo państw - fascynacja samorządnością. Przyczyną tej zbieżności są, jak można domniemywać, relatywnie niedawne doświadczenia obu państw naznaczone deficytem rzeczywistej decentralizacji władzy publicznej. W Polsce przesądził o tym całkowity brak samorządu terytorialnego w latach 1950-199040, w Japonii zaś jego fasadowość w okresie 1960-1999.

To nieoczywiste podobieństwo powoduje, że choć sięganie do japońskich wzorców prawnych może się wydawać przy pierwszym zetknięciu nieintuicyjne, warto jest rozważyć chociażby pobieżne odniesienie polskich regulacji do tamtejszych doświadczeń. Nie sposób przecież zaprzeczyć twierdzeniu, że wprowadzanie znaczących zmian w prawie (a takie w obszarze prawa samorządu terytorialnego wydają się nieodzowne) jest zdecydowanie łatwiejsze, gdy efektywność przedkładanych propozycji można uprzednio zweryfikować lub z czymś porównać. Komparatystykę prawną najczęściej prowadzi się w ramach tego samego kręgu kulturowego. Najwyższy czas zmienić to podejście. Od kultur dalekich też można się przecież wiele nauczyć. Charakteryzujące nieoczywiste refleksje prawno-porównawcze „świeże spojrzenie" daje szansę na realne (choć wcale niekoniecznie rewolucyjne) zmiany w prawie, a nie na ustawodawczą kosmetykę czy reformatorskie ruchy pozorowane. Być może więc zaproponowane wyżej japońskie inspiracje nie są wcale tak egzotyczne i nieprzydatne, jak mogłoby się wydawać.

\footnotetext{
38 Zob. L. Leszczyński, Japonia - kontynuacje i negacje, Lublin 1994, s. 26 i nn.

39 Zob. B. Bodziński-Guzik, Komitety negocjacyjnego tworzenia regulacji: analiza i krytyka rozwiazań normatywnych, „Internetowy Przegląd Prawniczy TBSP UJ” 2018, nr 1, s. 123 i nn.

40 H. Izdebski, Samorzad terytorialny. Podstawy ustroju i džiałalności, Warszawa 2004, s. 22.
} 
SUMMARY

\title{
THE MECHANISM OF COMMISSIONED TASKS \\ IN THE LAW OF LOCAL SELF-GOVERNMENT OF POLAND AND JAPAN: COMPARATIVE CONSIDERATIONS
}

\begin{abstract}
The Japanese local self-government system is a very characteristic model, standing out from the background of legal solutions adopted in this respect by other countries of the world. In addition to the distinction between Japanese local autonomy, collective autonomy and civic autonomy traditionally exposed in the doctrine, the distinctive feature of those legal solutions is the mechanism of commissioned tasks functioning since the 1999 reform, transferred to local self-government by central authorities (including the method of financing their implementation). Japanese experience, although seemingly distant, can be a reference point for the analysis of the functional dimension of the Polish local self-government system on the thirtieth anniversary of its reactivation.
\end{abstract}

